\title{
Metabolic Rate Quantification
}

National Cancer Institute

\section{Source}

National Cancer Institute. Metabolic Rate Quantification. NCI Thesaurus. Code C94933.

A quantification method to determine metabolic rate. 